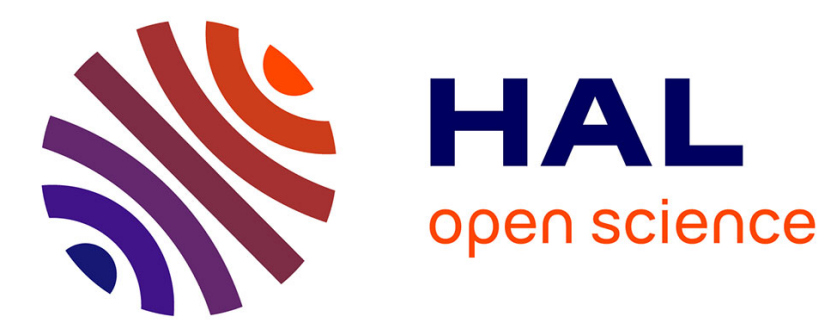

\title{
STUDY OF COPPER-ALUMINA BONDING
}

M. Courbiere, D. Treheux, C. Beraud, C. Esnouf, G. Thollet, Gilbert Fantozzi

\section{To cite this version:}

M. Courbiere, D. Treheux, C. Beraud, C. Esnouf, G. Thollet, et al.. STUDY OF COPPERALUMINA BONDING. Journal de Physique Colloques, 1986, 47 (C1), pp.C1-187-C1-192. 10.1051/jphyscol:1986128 . jpa-00225557

\section{HAL Id: jpa-00225557 https://hal.science/jpa-00225557}

Submitted on 1 Jan 1986

HAL is a multi-disciplinary open access archive for the deposit and dissemination of scientific research documents, whether they are published or not. The documents may come from teaching and research institutions in France or abroad, or from public or private research centers.
L'archive ouverte pluridisciplinaire HAL, est destinée au dépôt et à la diffusion de documents scientifiques de niveau recherche, publiés ou non, émanant des établissements d'enseignement et de recherche français ou étrangers, des laboratoires publics ou privés. 
JOURNAL DE PHYSIQUE

Colloque $\mathrm{C} 1$, supplément au $\mathrm{n}^{\circ} 2$, Tome 47 , février 1986 page $\mathrm{C} 1-187$

STUDY OF COPPER-ALUMINA BONDING

M. COURBIERE, D. TREHEUX, C. BERAUD*, C. ESNOUF* , G. THOLLET* and $G$. FANTOZZI*

Laboratoire de Métallurgie Physique, Ecole Centrale de Lyon, C.R.R.A.C.S., F-69131 Ecully Cedex, France

*Groupes d'Etudes de Métallurgie Physique et de Physique des Matériaux, C.C.R.A.C.S., (LA 341), INSA de Lyon, Bât. 502, F-69621 Villeurbanne Cedex, France

Résumé - L'adhésion entre un métal et une céramique peut être obtenue en comprimant à haute température les deux antagonistes sous faible pression (< $10 \mathrm{MPa}$ ) en atmosphère neutre. La liaison obtenue est testée mécaniquement par un essai de cisaillement de l'interface en fonction du temps et de l'oxydation du cuivre. L'interface et les ruptures sont observées et analysées à la microsonde de Castaing et en microscopie électronique en transmission.

Abstract - Bonding between a metal and a ceramic can be obtained by hot pressing of the two materials under low pressure $(<10 \mathrm{MPa})$ in protective atmosphere. In the present study this method was used to bond copper with alumina. The interface was assessed mechanically using a shear test as a function of time and copper oxidation. The bondind zone and the failures have been observed and analysed by electron probe microanalysis and transmission electron microscopy.

\section{I - INTRODUCTION}

Many joining techniques such as brazing have been performed using metallized alumina 11/. Alumina can aiso be bonded with another material by hot pressing using an intermediate metallic layer $12 \%$. In this case solid state reactions occur at the surface between the components. Difficulties in structural investigation of the interface explain why the mechanisms of adhesion are not actually well known. Three mechanisms can be distinguished :

- mechanical cohesion caused by the creep of the metal. Surface diffusion and evaporation/condensation phenomena have also to be considered in the filling of porosity and defects resulting from polishing $/ 3 /$,

- physical adhesion related to surface energies $/ 4 /$ is mainly responsible for bonding with noble metals $/ 5,6 /$ and non oxidized metals,

- chemical reaction between elements especially with reactive metals ( $\mathrm{Zr}, \mathrm{Ta}$, Nb) $17,8 /$ occurs through a redox reaction. Chemical reactions also take place between different oxides $19 /$. 
The bonding of copper to alumina is interesting because all three mechanisms are probably present since copper has a good ductility and binary oxides exist.

\section{II - EXPERIMENTAL PROCEDURE}

The materials used were polycristalline alumina $(99,7 \%$ Degussit Al 23$)$ and $0 . F . H$. copper. After cutting, ceramic samples were polished using $6 \mu \mathrm{m}$ diamond powder to a finish approaching optical flatness, then air annealed 1 hour at $1000^{\circ} \mathrm{C}$. Copper sheet was cold rolled down to $0.2 \mathrm{~mm}$, after which $5 \mathrm{~mm}$ diameter discs were pressed out of the sheet material. These discs were polished using $3 \mu \mathrm{m}$ diamond powder and then vacuum annealed $\left(10^{-3}\right.$ torr, $\left.30 \mathrm{mn}, 1000^{\circ} \mathrm{C}\right)$. Superficial oxidation of the copper (Cu20) was obtained by heating up to $1000^{\circ} \mathrm{C}$ under low oxygen atmosphere.

Solid state bonding was performed in an argon atmosphere at $1000^{\circ} \mathrm{C}$ by compression of one or several alternated sheets of alumina and copper. The pressure was $4 \mathrm{MPa}$ and the time of treatment was varied from $30 \mathrm{~min}$ to 6 hours, the heating rate being $5^{\circ} \mathrm{C} / \mathrm{min}$. After treatment the samples were furnace-cooled.

The strength of the interface was measured by a shear test at room temperature with a strain rate equal to $5 \mathrm{~mm} / \mathrm{min}$. The T.E.M. observations were made on transverse foils using a Jeol $200 \mathrm{kV}$ microscope. These foils were prepared by mechanical polishing and finally by ion bombardment.

\section{III - EXPERIMENTAL RESULTS}

Figure 1 shows the shear test results. A decrease of the shear strength is observed for long time treatment. The examination of the surface after failure shows the existence of three areas (Fig.2), distinguishable both visually by coloration and by S.E.M. observations. These reveal that copper deformation differed in the three areas; the compounds localized at the interface were also different.

In zone III observation and analys is of the two faces after failure indicated the presence of one oxide on both of them (Fig.2D). Yet for long time treatment and for less oxidized copper samples the oxide tends to disappear. T.E.M. observations in the same zone confirm this difference :

- for treatment of two hours with an initial $\mathrm{Cu}_{2} \mathrm{O}$ thickness of $0.7 \mu \mathrm{m}$, a binary oxide $\mathrm{CuAlO}_{2}$ is present at the interface (Fig.3a). The compound $\mathrm{CuAlO}_{2}$ contains many twins running parallel to the interface. No crystallographic relations exist between the three materials,

- for treatment of six hours with the same initial thickness of Cu20 /12/, the binary oxide is not found, instead of it there is a layer of alumina (Fig.3b) which is microcrystalline and whose thickness is close to that of the binary oxide. Moreover $\mathrm{Cu}_{2} \mathrm{O}$ nodules are detected in the bulk copper or near the interface (Fig 3c).

The zone II has an annular shape; the copper oxide disappears when its initial thickness is under $1 \mu \mathrm{m}$. Copper metal shows a ductile deformation mode; the dimples (Fig. $2 \mathrm{C}$ ) are filled up with thin precipitates of $\mathrm{Cu}_{2} \mathrm{O}$. This is the real zone of adhesion; no chemical reaction seems to occur between $\mathrm{Cu}_{2} \mathrm{O}$ and $\mathrm{Al}_{2} \mathrm{O}_{3}$. This zone does not exist for the highest level of pre-oxidation.

The zone I shows variable adhesion, this part is in contact with the furnace atmosphere, reactions take place with alumina. Pits filled with copper spheres are present in the ceramic (Fig.2d).

IV - DISCUSSION

The mechanisms of plastic deformation of the metal by creep during the compression, between two non deformable surfaces, are described in literature $/ 10 \%$. Solid state bonding areas have been studied by $k 1$ omp $/ 11 /$. The different cases depend essentially on friction phenomena between metal and ceramic. The understanding of the physical and chemical phenomenas occuring at the interface necessitates a deep knowledge of the mechanical processes involved in this area of the sample. The three zones observed can be related to the different stress situations which exist in the copper (Fig.2a). 

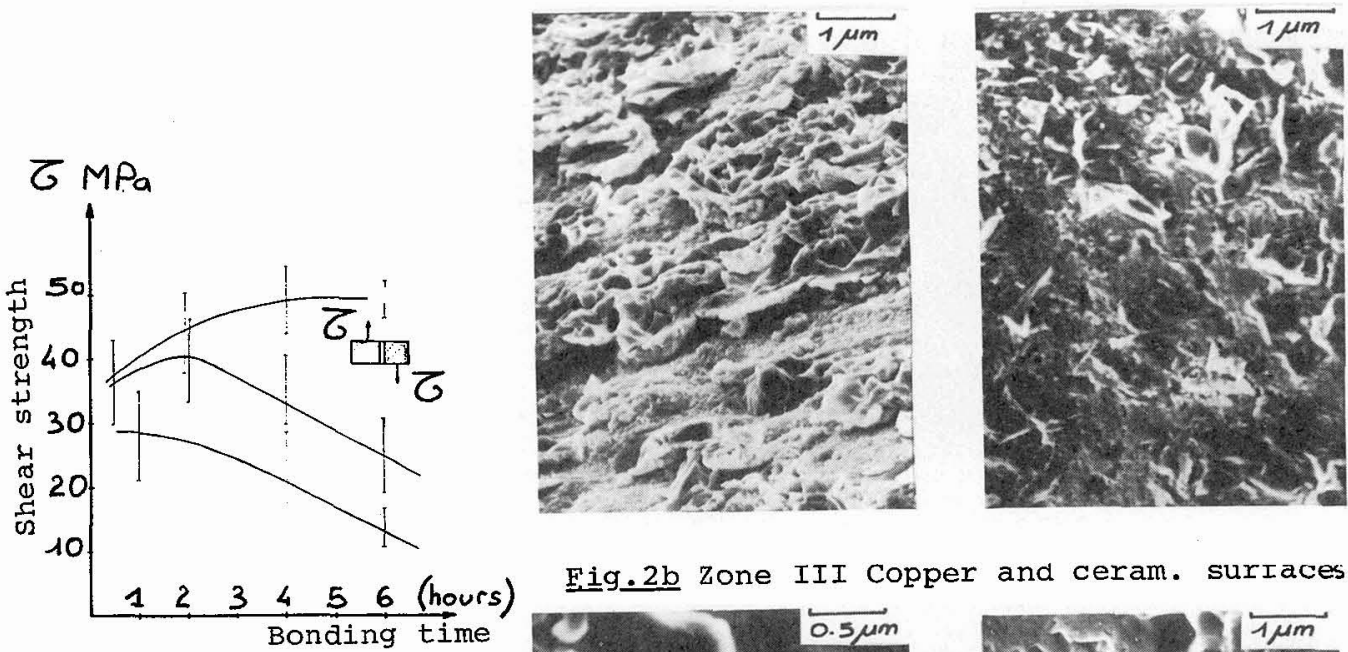

Fig. I The effects of bondin time and Cu-preoxidation or: bond strength.

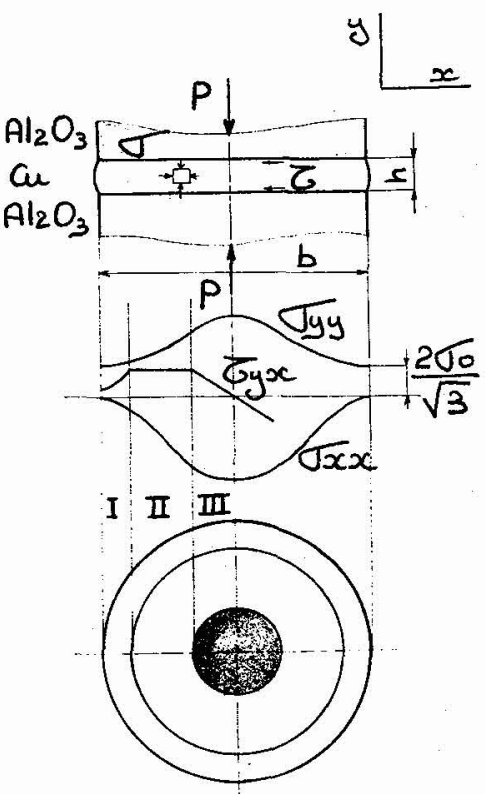

Fig. 2a The three zones of bonding and the calculated Fig.2b Zone III Copper and ceram. surraces
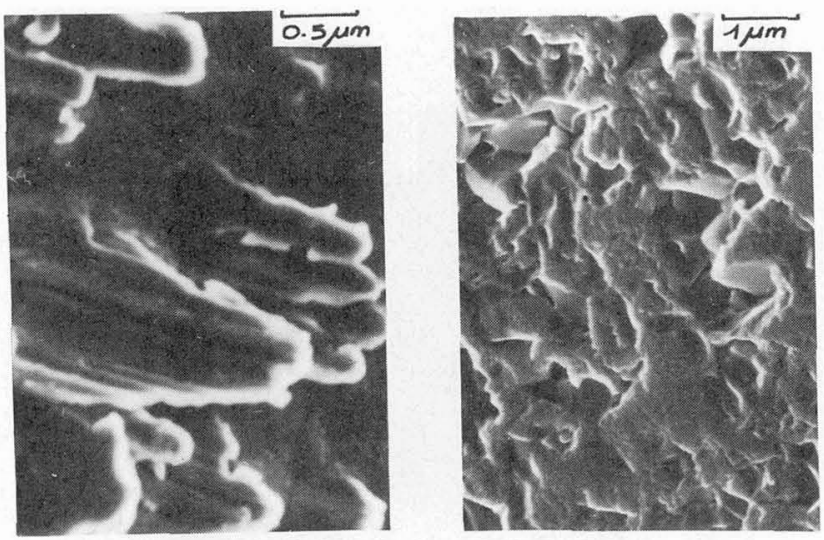

Fig.2c Zone II Copper and ceram. surfaces
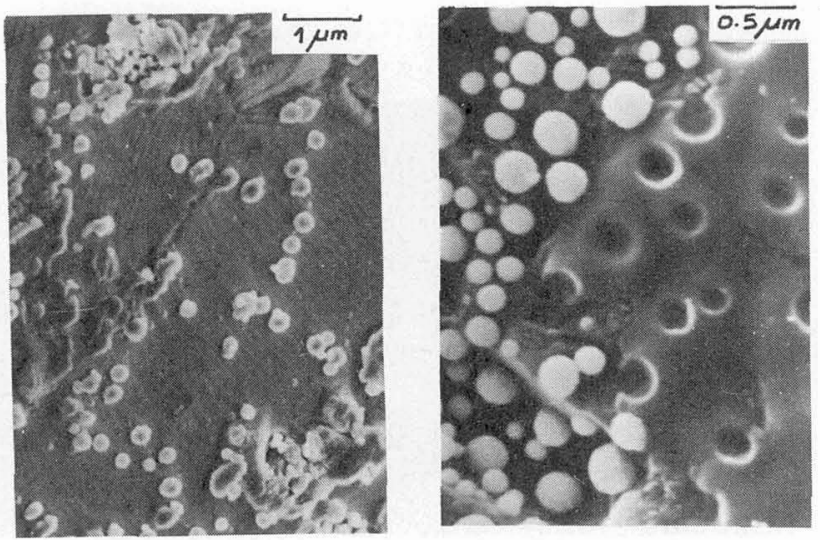
stress distribution in them.

Fig.2d Zone I copper and ceramic surfaces Fig.2 Different areas after failure :

S.E.M observations 

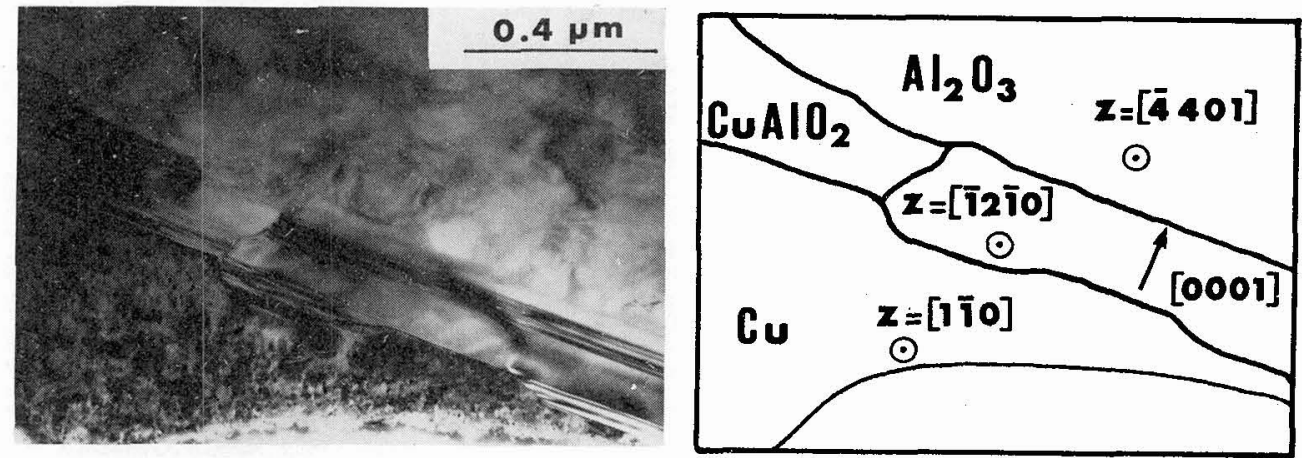

Fig. 3a T.E.M micrograph showing binary oxide present at the interface ( 2 hours $1000^{\circ} \mathrm{C} 4 \mathrm{MPa}$ )
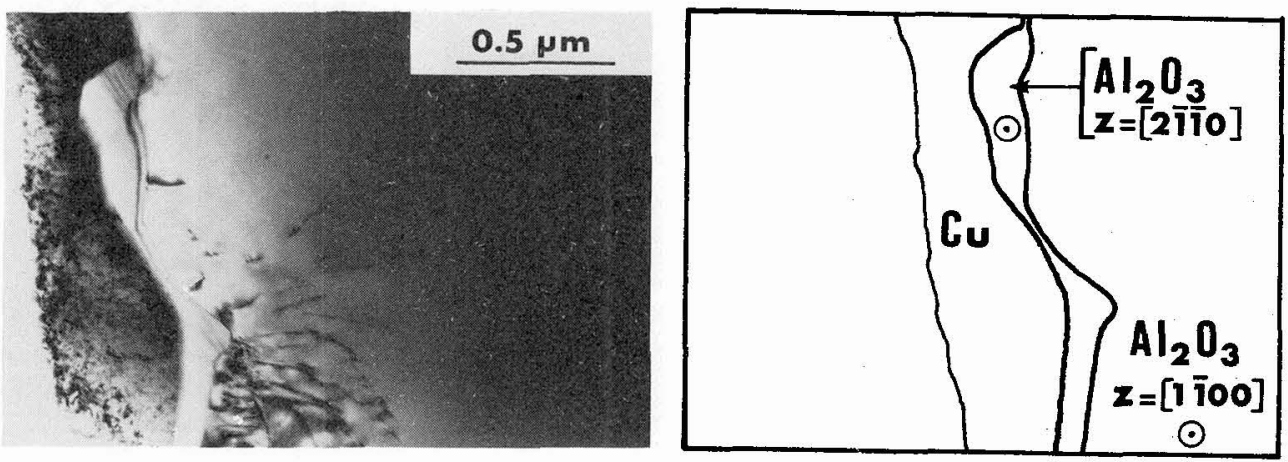

Ejg. 3b Recrystallized alumina ( 6 hours $\left.1000^{\circ} \mathrm{C} 4 \mathrm{MPa}\right)$
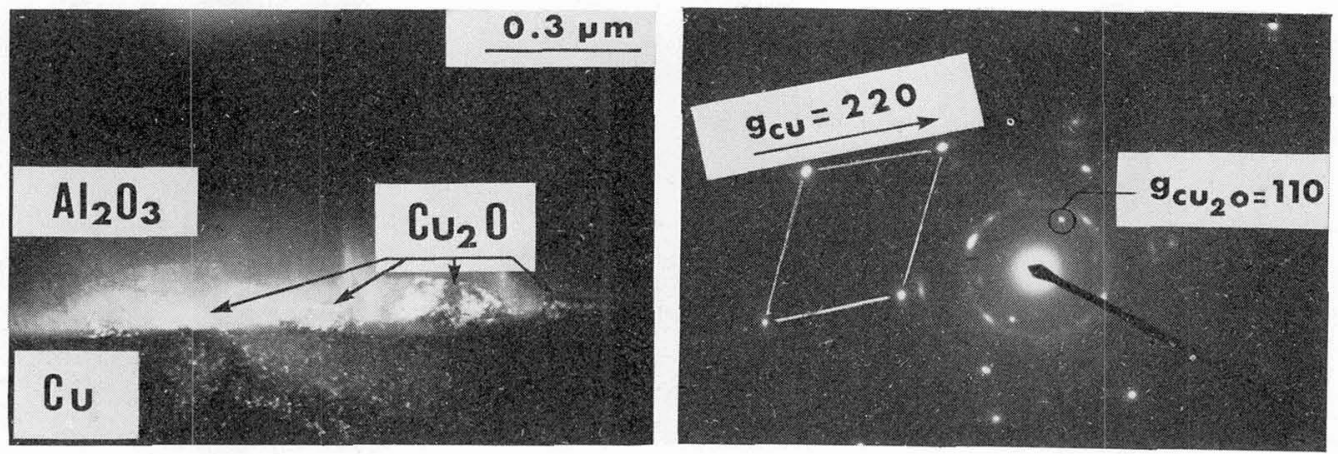

Fig. $3 c$ Diffraction pattern and dark field image with ${ }^{9} \mathrm{Cu}_{2} \mathrm{O}=110$ 
In the central zone III normal stress is maximum and shear stress is minimum. At the beginning a Cu/Cu2 $\mathrm{O}_{\mathrm{A}} \mathrm{T}_{2} \mathrm{O}_{3}$ interface is present (Fig.4a), then $\mathrm{Cu}_{2} \mathrm{O}$ oxide reacts with alumina to form $\mathrm{CuAlO}_{2}$ binary oxide ( $\mathrm{Fig} .4 \mathrm{~b}, 3 \mathrm{a}$ ) in accordance with :

$$
\mathrm{Cu}_{2} \mathrm{O}+\mathrm{Al}_{2} \mathrm{O}_{3} \underset{2}{\stackrel{1}{\longrightarrow}} 2 \mathrm{CuAlO}_{2}
$$

T.E.M studies indicate that the binary oxide is plastic related because mobile dislocations have been observed /12/.The compact layer of $\mathrm{Cu}_{2} \mathrm{O}$ is progressively reduced to small nodules situated in the bulk copper (Fig.4c). When the amount of $\mathrm{Cu}_{2} \mathrm{O}$ becomes insufficient, the reaction reverses and the binary oxide is destabilized ( $F$ ig.4d,3b,3C). Cuzo particles dissolve in copper by continuous diffusion of oxygen which has a limit of solubility of 0.009 wt $\%$ at $1000^{\circ} \mathrm{C}$.

The stability of cualuz seems to be very sensitive to an equilibrium with the amount of oxygen (atmosphere, dissolved oxygen,otiner oxide). The reaction 1 occurs for high oxygen levels and reaction 2 for low oxygen levels.

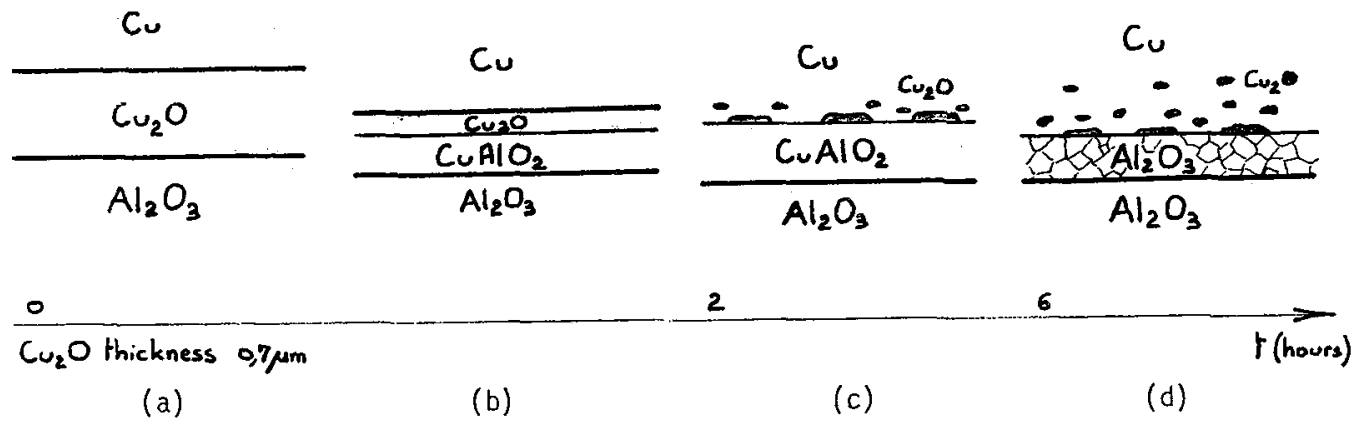

Fig.4 Evolution of the interface in zone III

In zone II the nigh shear stress leads either to the decrease of incubation time of reactions 1 and 2 (promoting the elimination of binary oxide) or to fragmentation of Cuzu oxide layer. The surface diffusion of copper atonis on the ceramic leads to close contact Detween the phases. This pirenomenon accelerates the dissolution of the oxides as mentioned in $/ 11 /$.

The zone $I$ is not subjected to higin stress. The presence of cavities on the alunina surface shows that curv oxide reacts witil aluaina according to reaction 1. Copper spheres indicate that the reduction of oxides has occured as a consequence of the low oxygen level in the furnace.

$v$ - CuBrilusiuin

The bonding between alumina and oxidized copper obtained by solid state bonuing $\left(1000^{\circ} \mathrm{C}\right.$ 4i. Pa) has veen tested using a snear test and investigated by S.F. il. and by T.F.N. odservations. The cuAlo $0_{2}$ oxide which develops at the beginning of the treatrient is destauilized in favour of $\mathrm{H}_{2} \mathrm{U}_{3}$ and $\mathrm{Cu}_{2} \mathrm{U}$ uy diffusion of oxygen. This can ve correlated to tne decrease of the bonding strength.

RFFFKFWCFS

/i/ J.T Klonp, Powder metallurgy international vol $3 n^{\circ} 4$ (i971) pliz2.

IL/ W. wicholas ancik.ii irispin, Proc.3rit.Ceram.Soc. $n^{\circ} 32$ p33.

$13 \mathrm{~J} \mathrm{J.T} \mathrm{Klomp,} \mathrm{lerawic} \mathrm{dulletin} \mathrm{vol} 51 \mathrm{n}^{\circ} \mathrm{g}$ (1972) po83.

14/ A.C.D Chakalder, W.w Gill and S.P Netrotra, Surfaces and interfaces in ceranic and ceramic metal systemes (1981) Fd. Plenum vol 14 pizi.

/b/ F.P bailey and K.J.T black, Journal of material science vol 13 (iy78) piu4j. 
10) K.V Allen and w.E sorbidge, idem ref. 4 p2835.

17/ G. Flssner, W. Diem and J.S wallace, idem ref. 4 poz9.

/8/ G. Heidt and G. Heinke, Ber. Dt. Keram. Ges vol $50 n^{\circ} y$ (1973) psu3.

/y/ F.P Bailey and i.E Borbidge, idem ref.4 p 525 .

/iof P. Baque, F. Felder, J. Hyafil and $Y$. Descatina, hise en forne des inetaux :calcul par la plasticite, Eu.Dunod.

11i/ J.T Klomp and A.J.C Van de Ven, Journal of material science vol 15 (1980) p2483.

/12/ C. Beraud, M. Courbiere, G. Thollet and C. Esnouf, Colloque S.F.A.F. Strasbourg (1985).

Acknowlegments : The authors are grateful to the ORFT (contrat 83.519) for support or this work. 